\title{
Is accident frequency a reliable indicator of industrial conflict?
}

\author{
John Penney and Nick Hamilton*
}

This article presents the results of research into the relationship of labour turnover, absenteeism and accident frequency to organised manifestations of industrial conflict in a New Zealand industrial environment. It supports previous research findings of an additive relationship between labour turnover and absenteeism and lost time due to industrial disputes. However, an inverse relationship is found between accident frequency and the other three expressions of conflict. A possible reason for this anomaly is proposed.

\section{Introduction}

The New Zealand approach to the study of industrial accidents has somewhat belatedly tended to follow that of the United Kingdom and focus increasingly on the social relationships of people to their work. The classic study is that of Hill and Trist (1953), who, in an examination of accidents in the British steel industry, found that those workers who were most prone to lost time accidents were also most prone to absenteeism of other kinds. This led to formulation of the withdrawal hypothesis, whereby accidents are considered as a "means of withdrawal from the work situation through which the individual may take up the role of absentee in a way acceptable both to himself and to his employing organisation." (p.359). About twenty years later, a New Zealand article heralded a "new approach", "... drawing attention to the characteristics of the social relationship of people to their work" (Department of Labour 1972), and concluded that "behind much sick leave, many accidents and sudden rises in staff turnover are individual stories of job dissatisfaction, low morale, bad communications and conflict with a workmate or boss." (p.21).

An important debate has centred on the question of whether there is a direct, additive or inverse, substitutive relationship between the organised manifestations of conflict such as strikes and these individual, unorganised withdrawals. The debate is well summarised by Bean (1975) who notes that the studies examining this question "have tended to confine themselves to a micro-level examination." (p.99). Bean's own study examined the question on the macro-level, by comparing statistics for each of 16 British manufacturing industries for strikes, voluntary absence, sickness and late arrival and concluded "that organised and unorganised expressions of conflict are linked by means of a direct and additive, rather than an inverse connection" (p.101). Previously Handy (1968) in his study of the British coalmining industry had suggested that strikes and absenteeism were substitutive whereas Revans (1956) found, in the same industry, that larger units suffered lower worker morale, and as a consequence a higher incidence of strikes, absenteeism and accidents; an additive relationship. To further confuse the issue, a study of Labour Relations in the British Motor Industry (Turner et al 1967) found no significant connection either direct or inverse between collective demonstrations of grievance and the other forms of withdrawal.

* John Penney is Industrial Relations Officer with NZ Motor Corporation. Nick Hamilton is Industrial Relations Manager. They gratefully acknowledge the helpful criticism and suggestions made by the journal referees and editor. 
However, there has been increasing acceptance of a direct, additive relationship by both students and practitioners in Industrial Relations and the present authors have been no exception to this trend. A recent article by Beaumont (1979) which found a positive, though non-significant relationship between accidents and absenteeism in a Scotland road transport company adds further weight to this view.

\section{A Macro Approach}

As noted earlier, most studies have taken a micro-approach to the problem and focussed on a deviant minority of workers. However, a macro-approach is likely to be of most value to the practitioner, as an understanding of the way in which different forms of withdrawal are related might enable him to detect changes in the industrial environment, resulting in some useful prediction or warning. For example, a personnel manager subscribing to the additive relationship view, on observing an overall increase in accident frequency, might predict a greater likelihood of organised industrial disruption. For this reason, the present study took a macro approach.

The authors are employed in corporate Industrial Relations capacities by the New Zealand Motor Corporation, a company with three motor vehicle assembly plants. The plants regularly report statistics for lost time due to industrial action (strikes and stopwork meetings), absenteeism, labour turnover, and accident frequency. These statistics are used for control purposes, and while the use of the first measurement is self-evident, the other three statistics have been used on a regular basis also as indicators of the state of Industrial Relations in each plant. It was decided recently, to collate all four measurements in one table for comparison. The purpose of this was to see whether a direct additive relationship between the four types of withdrawal would hold true in this New Zealand industry.

In order to gain maximum value from such a comparison it was also necessary to determine the degree of consistency between the plants in their accident reporting. Reporting procedures are certainly the same from a control viewpoint. However, while strikes, absenteeism and labour turnover are all open to hard objective measurement, accidents are "measured" by the victim. Senneck (1975) argues the optional nature of some absences from injury in his severity threshold model and points out that where the threshold for absence due to injury is low, the average lost time per accident would be reduced by the greater number of accidents. Therefore, some indication of the accident severity threshold in each plant was required. Two measures were used. First, the mean cost per lost-time accident in wages paid out for the first week for Accident Compensation, which gives an approximation to the mean lost time per accident for comparative purposes. ${ }^{1}$ Secondly the incidence of "strains and sprains", which as Senneck (1975) notes, are invisible and traditionally suspect, as a proportion of all lost-time accidents.

\section{Results}

The hypothesis suggested by the authors' search of the literature was that the plant with the highest incidence of lost time through collective industrial action would also have high absenteeism, labour turnover and accident frequency. Conversely, the plant with the lowest incidence of lost time through collective industrial action would have low absenteeism, labour turnover and accident frequency. For the purpose of clarity the results have been split into two tables.

Table 1 establishes some minor differences in mean cost per accident and incidence of sprains and strains between the plants but these are not of sufficient magnitude to conclude different accident reporting thresholds. Plant $\mathrm{Y}$ and Plant $\mathrm{Z}$ appear very similar. Therefore,sthreshold can be considered to be more or less constant.

1 Actual lost time per accident was not recorded in 1979 beyond this first week and therefore could not be used. 
Table 1 Accident reporting threshold indicators 1979 and 1980 combined

\begin{tabular}{cccc}
\hline & \multicolumn{3}{c}{ Plant } \\
\cline { 2 - 4 } & $\mathrm{X}$ & $\mathrm{Y}$ & $\mathrm{Z}$ \\
\hline $\begin{array}{c}\text { Mean cost in wages paid } \\
\text { per lost time accident (\$) }\end{array}$ & 115 & 92 & 90 \\
$\begin{array}{c}\text { Proportion of total lost time } \\
\text { accidents due to "sprains } \\
\text { and strains" (percent) }\end{array}$ & 35 & 48 & 54 \\
\hline
\end{tabular}

Immediate differences between the plants are apparent in the first part of the second table. Plant, Y, appears as the epitome of poor industrial relations - high absenteeism, high lost time through collective industrial action, and high labour turnover. Plant $\mathrm{X}$ is little better. By contrast, Plant $\mathrm{Z}$ appears as a model of harmonious Industrial Relations - very little time lost through collective industrial action, low absenteeism and low labour turnover. These results, therefore, confirm the hypothesis with respect to absenteeism, labour turnover and collective industrial action - a direct additive relationship was found between these three measurements.

Table 2 (i) Assembly plant industrial statistics

\begin{tabular}{|c|c|c|c|c|c|c|}
\hline & \multicolumn{6}{|c|}{ Plant } \\
\hline & \multicolumn{2}{|c|}{$\mathrm{X}$} & \multicolumn{2}{|c|}{$\mathbf{Y}$} & \multicolumn{2}{|c|}{ Z } \\
\hline & 1979 & 1980 & 1979 & 1980 & 1979 & 1980 \\
\hline Average employment & 320 & 356 & 410 & 317 & 308 & 273 \\
\hline $\begin{array}{l}\text { Mean quarterly time loss } \\
\text { through industrial action } \\
\text { (percentage of available } \\
\text { time) }\end{array}$ & 1.6 & 7.0 & 5.3 & 12.7 & 0.5 & 0.6 \\
\hline $\begin{array}{l}\text { Mean weekly absenteeism } \\
\text { (percent) }\end{array}$ & 7.8 & 8.2 & 7.8 & 8.5 & 3.9 & 3.7 \\
\hline $\begin{array}{l}\text { Annual staff turnover } \\
\text { (percent) }\end{array}$ & 57.0 & 52.0 & 44.0 & (a) & 23.0 & (a) \\
\hline
\end{tabular}

(a) Not available

Table 2 (ii) Assembly plant industrial statistics

\begin{tabular}{|c|c|c|c|c|c|c|}
\hline & \multicolumn{6}{|c|}{ Plant } \\
\hline & \multicolumn{2}{|c|}{$X$} & \multicolumn{2}{|c|}{$Y$} & \multicolumn{2}{|c|}{$\mathrm{Z}$} \\
\hline & 1979 & 1980 & 1979 & 1980 & 1979 & 1980 \\
\hline $\begin{array}{l}\text { Accident frequency rate } \\
\text { (per } 1000 \text { man hours, } \\
\text { adjusted for time lost } \\
\text { in strikes) }\end{array}$ & 1.8 & 1.7 & 2.4 & 2.7 & 6.2 & 5.1 \\
\hline
\end{tabular}


An examination of the second part of the table, however, does not bear out the hypothesis as far as accident frequency is concerned. The highest accident frequency was found at Plant $\mathrm{Z}$ while substantially lower accident frequency rates are recorded for the other two plants. As stated earlier there are no differences in reporting methods or thresholds to explain this difference and the work methods and equipment are similar in type and operation in all three plants.

In summary, this macro-examination thus confirms a direct general relationship between the organised manifestations of industrial conflict, that is lost time through collective action, and the unorganised manifestations of absenteeism and labour turnover. However, an inverse relationship appears in this case between accidents and the other measurements with Plant $Z$ having an accident frequency rate between two and three times higher than the other plants. Therefore, in this New Zealand industry accident frequency cannot be considered a reliable indicator of industrial conflict.

\section{Discussion}

The results do not totally preclude a direct relationship between accidents and other parameters of conflict under certain conditions. The most recently published study by Beaumont (1980) found a positive relationship between serious accidents and strikes. It seems probable that a high incidence of serious accidents in an industry would predispose workers to direct forms of withdrawal and become itself central to industrial conflict.

It was beyond the scope of this research design to properly analyse the various micro factors in a systematic manner in order to try to explain this apparent anomaly. However, some clues from the authors' at least partly enlightened speculation may assist future research and suggest where this could usefully be directed.

The first clue comes from a neglected aspect of the withdrawal hypothesis of Hill and Trist (1953) which suggests that the worker who has accidents seeks approval for his withdrawal because he takes up "the role of absentee in a way acceptable both to himself and his employing organisation." (p.359). Considerable support for this appears in an early study by Castle (1956) of accidents and absenteeism at a light industrial factory in outer London. Castle found that "accidents are seen to be most associated with leave with permission - the most sanctioned form of absence - and least associated with leave without permission - the least sanctioned form." (p.230).

The second clue also comes from Castle, where he concludes "if the same trends are not observed ... it is perhaps because (the) social aspects of the relationship of people to their work are also dissimilar." (p.231). Could it be that at Plant $\mathrm{Z}$ important social variables differ dramatically from the other two plants which mean that workers at $Z$ will seek approval for withdrawal, while the other plants' workers will not?

An examination of the work forces at each plant suggests this is so. Workers at Plant $\mathrm{X}$ and $\mathrm{Y}$ are predominantly Polynesian and there is a larger proportion of younger workers than at Plant $\mathrm{Z}$. Workers at Plant $\mathrm{Z}$ are almost entirely Caucasian with a greater proportion of older married men. How could this difference affect the attitudes of workers to withdrawal from a work place? The solution probably lies in socialisation. Workers at Plant Z being Caucasian and older are socialised into the norms of the Protestant work-ethic. They have, therefore, internalised the values of hard work, loyalty to an employer, responsibility to provide for their families and so on. Individual responsibility is a keystone to their work behaviour and this is reinforced by the contingencies of children at school, mortgages and community expectations. Moreover these workers are drawn from a semirural and small town environment in which permanence is a dominant characteristic, therefore, permanent employment is not to be put at risk. 
On the other hand, workers at Plant $\mathrm{X}$ and $\mathrm{Y}$ are less likely to have internalised these values. Many have not been brought up in a Western Culture, others are younger and grew up when the work-ethic was being increasingly questioned. For the Polynesian, individual responsibility for material well-being is, to some degree, subjugated to community responsibility. Furthermore, the workers in Plant $\mathrm{X}$ and $\mathrm{Y}$ are drawn from urban industrial environments where transience is a dominant characteristic.

What is common for workers in all plants is the type of work. It is generally accepted that working on an assembly line is not the most intrinsically satisfying or independent of jobs. Not that this is fatal to harmonious Industrial Relations for as Kerr Inkson (1977) suggests, whether an intrinsic orientation to work is more natural than an extrinsic orientation is a matter for dispute. The authors are inclined to agree with his assertion that "the values which intrinsic theory prescribes are the values of middle class people . . . and it is wrong to assume they are right for everyone" (p.15). Nevertheless, it is suggested here that a certain basic conflict arises between the workers and the line out of this lack of intrinsic reward. However, for workers at Plant $\mathbf{Z}$ there is a powerful extrinsic orientation to work through the internalised values of the Protestant ethic. Therefore, the worker cannot deliberately and with hostility withdraw from the workplace. Strikes, absenteeism and leaving the job are as unacceptable to him as he knows they are to his employer. The conflict, then, is at its most powerful not externally, between him and the workplace or employer, but in his own mind. At times this conflict produces in the worker a state of anxiety which leads ultimately to the reporting of an accident. This could happen either because the anxiety makes the worker more accident prone or because less serious accidents could be rationalised as requiring time off work. The first explanation is probable in this case because, as we have already seen, there is little difference in severity thresholds for reporting between the plants. However, either possibility would produce the same results on the Macro level, that is, a higher lost time accident frequency. The end result is that the worker is able to withdraw from the work place by taking up, in the words of Hill and Trist (1953) "the role of absentee in a way acceptable both to himself and to his employing organisation" (p.359), and the state of anxiety is thereby relieved.

Workers at the other plants have a different orientation. Therefore, the conflict that arises remains external, between the worker and the workplace or employer. The way for him is clear for a deliberate and often hostile withdrawal from the workplace which will take the form of absenteeism, or leaving the job, or, with other workers, a form of industrial action.

\section{Conclusions}

This paper may be summarised as follows:

1. There is a direct additive relationship between absenteeism and labour turnover (unorganised manifestations of conflict) and collective industrial action (organised manifestations of conflict).

2. Accident frequency does not belong to this pattern and no direct relationship was found to exist between accidents and the above-mentioned manifestations of conflict. A suggested reason for this is that absenteeism, turnover and strikes are deliberate, hostile acts, but accidents are seen to 'happen' to the worker and, therefore, allow him to withdraw from the workplace in a manner which is acceptable to the worker and his employer. It is evident then that accident frequency cannot serve as a reliable indicator of industrial conflict because of its uncertain relationship with the more obvious manifestations.

3. It is certain that social and cultural differences are of considerable importance to questions of accident frequency and the clearly, positively related indicators of conflict, whether organised or unorganised and the authors look forward to further New Zealand research which examines this area more rigorously. 


\section{References}

Bean, R. (1975) The relationship between strikes and 'unorganised' conflict in manufacturing industries British journal of industrial relations 13 (1):98-101.

Beaumont, P. (1979) The relationship between industrial accidents and absenteeism Industrial relations journal $10(3): 54-56$.

Beaumont, P. (1980) An analysis of the problem of industrial accidents in Britain International journal of manpower 1 (1) : 28-32.

Castle, P.F.C. (1956) Accidents, absence and withdrawal from the work situation Human relations 9 (2) : 223-233.

Department of Labour (1972) Employee relations: a guide to accident prevention Labour and employment gazette 22 (3): 18-21.

Handy, L.J. (1968) Absenteeism and attendance in the British coalmining industry British journal of industrial relations 6 (1) : 27-50.

Hill, J.M.M. and Trist, E.L. (1953) A consideration of industrial accidents as a means of withdrawal from the work situation Human relations 6 (4) : 357-380.

Inkson, J.H.K. (1977) Job satisfaction and work improvement: a modern dilemna Journal of public administration 39 (1) : 13-19.

Revans, R.W. (1956) Industrial morale and size of unit Political quarterly 27(3):303-311.

Senneck, C.R. (1975) Over 3-day absences and safety Applied ergonomics 6 (3):147-153.

Turner, H.A., Clark, G. and Roberts, G. (1967) Labour relations in the motor industry: a study of industrial unrest and an international comparison London, Allen and Unwin. 